\title{
Patients' Rights, Medical Error and Harmonisation of Compensation Mechanisms in Europe
}

\author{
Kenneth Watson \\ Independent Healthcare Consultant; Doctoral candidate, Institute of Health \\ Policy and Management, Erasmus University Rotterdam, Rotterdam, \\ The Netherlands \\ watson@bmg.eur.nl \\ Rob Kottenhagen \\ Associate Professor, Faculty of Law, Erasmus University Rotterdam, Rotterdam, \\ The Netherlands
}

\begin{abstract}
In 1999 the Institute of Medicine reported that most medical injuries relate to unavoidable human error in a context of system failure. Patient safety improves when healthcare providers facilitate blame-free reporting and organisational learning. This is at odds with fault-based civil liability law, which discourages a more open (doctorpatient) communication on medical injuries. The absence of a clear-cut definition of 'medical error' complicates litigation and hence swift, appropriate patient compensation. No-fault systems perform better in this respect. A dual track liability system for medical malpractice is challenging to implement and operate, yet may be the only option for Pan-European harmonisation of medical liability.
\end{abstract}

\section{Keywords}

informed consent - medical error - litigation - no-fault system - patient safety 


\section{Introduction}

1.1 Doctor-patient Relationship, Healthcare Quality and Patient Safety The doctor-patient relationship is shaped by the quality and manner of information exchange. This is a delicate process with case-specific relational and communication elements, ${ }^{1}$ which all affect deliberation and decision-making on the most appropriate course of care. Despite greater patient access to medical information clinical practice is still characterised by considerable physician-patient information asymmetry. ${ }^{2}$ Conscientious efforts for more effective implementation of the informed consent doctrine ${ }^{3}$ as codified in the European Convention on Human Rights \& Biomedicine, ${ }^{4}$ the Charter of Fundamental Rights of the European Union $(\mathrm{EU})^{5}$ and national or case law of EU Member States ${ }^{6}$ remain essential to enhance patient autonomy. ${ }^{7}$ Especially in a paternalistic hospital environment reinforcing the patient's capacity and competency to consent isn't a luxury. ${ }^{8}$ In this context poor doctor-patient interaction and suboptimal sharing of 'essential' medical information are common causes of patient dissatisfaction. There is ample empirical evidence of a strong correlation between communication failures and medical malpractice

1 E.J. Emanuel et al., 'Four models of the physician-patient relationship', JAMA 267 (1992) 1222; G. Elwyn et al., 'Shared Decision Making: A Model for Clinical Practice', Journal of General Internal Medicine 27 (2012) 1361.

2 D.L. Frosch et al., 'Authoritarian Physicians and Patients' Fear of Being Labeled 'Difficult' among Key Obstacles to Shared Decision Making', Health Affairs 31 (2012) 1030-1038.

3 C. Grady, 'Enduring and emerging challenges of informed consent', New England Journal of Medicine 372 (2015) 855-862; E.S. Spatz, 'The New Era of Informed Consent', JAMA 315 (2016) 2063 .

4 See Arts. 5, 8, 9 and 10.

5 See Art. 3 .

6 See e.g. Arts. 7:448-449 Medical Treatment Agreements Act (NL); Art. L. 1111-2 CSP (F) and Cass. Civ. (1), 23 January 2014, no. 12-22123 (F); Bolam v. Friern Hospital Management Committee (1957) 1 WLR 582 and Montgomery v. Lanarkshire Health Board (2015) U KSC 11 (U K).

7 S.F. Birkeland, 'Informed Consent Obtainment, Malpractice Litigation, and the Potential Role of Shared Decision-making Approaches', European Journal of Health Law 24 (2017) 264-282.

8 R. Heywood et al., 'Patient perceptions of the consent process: qualitative inquiry and legal reflection', Journal of Professional Negligence 24 (2008) 104. Patients perceive information disclosure by doctors as an effort to dodge liability rather than as sincere facilitation of their well-informed, genuine consent to their treatment. The Supreme Court's landmark ruling in Montgomery v. Lanarkshire Board (2015) reinforced patients' rights in the UK; see M. Campbell, 'Montgomery v Lanarkshire Board', Common Law World Review 44 (2015) 222-228. 
litigation. ${ }^{9}$ Physicians find it difficult to gauge what sort of information patients exactly require and when the 'right' level of understanding is achieved to render their consent legally and ethically valid. ${ }^{10}$ Analyses of the communication and behaviour of physicians, who never experienced a malpractice lawsuit, and those, who had previously been sued, reveal that the latter have deficient interpersonal skills. They often struggle to develop (emotionally) meaningful interactions with patients. ${ }^{11}$

There is no difference in quality of care involved. ${ }^{12}$ A recent literature review on the role of shared decision-making in reducing medical litigation supports this observation. Professional arrogance and failure to diagnose or respect patient preferences put clinicians at higher risk of litigation, in particular when they also make little effort to enhance patient understanding of possible treatment harms and benefits. ${ }^{13}$ Statistics show only a small minority of doctors is complaint/claim-prone. Yet they account for a disproportionally large number of malpractice lawsuits. ${ }^{14}$ Prospective identification and proactive peer counselling and/or monitoring of these 'bad apples' might result in less litigation and better healthcare. ${ }^{15}$

This is important in the context of (improving) patient safety and patient satisfaction, as the volume and complexity of medical interventions steadily

$9 \quad$ C. Vincent et al., 'Why do people sue doctors? A study of patients and relatives taking legal action', Lancet 343 (1994) 1609-1613; H.T. Stelfox et al., 'The relation of patient satisfaction with complaints against physicians and malpractice lawsuits', American Journal of Medicine 118 (2005) 1126-1133; D. Roter, 'The patient-physician relationship and its implication for malpractice litigation', Journal of Health Care Law \& Policy 9 (2006) 304-314.

10 R. Heywood et al., 'Informed consent in hospital practice: health professionals' perspectives and legal reflections', Medical Law Review 18 (2010) 152.

11 N.C. Meruelo, 'Mediation \& Medical Malpractice', Journal of Legal Medicine 29 (2008) 289.

12 W. Levinson et al., 'Physician-patient communication. The relationship with malpractice claims among primary care physicians and surgeons', JAMA 277 (1997) 553-559.

13 M. Durand et al., 'Can shared decision-making reduce medical malpractice litigation? A systematic review', BMC Health Services Research 15 (2015) 167-178.

14 D.M. Studdert et al., 'Prevalence and Characteristics of Physicians Prone to Malpractice Claims', New England Journal of Medicine 374 (2016) 354-362. 'Approximately 1\% of all physicians accounted for $32 \%$ of paid claims'; M.M. Bismark et al., 'Identification of doctors at risk of recurrent complaints: a national study of healthcare complaints in Australia', BMJ Quality and Safety in Health Care 22 (2013) 532-540. '(...) 3\% of Australia's medical workforce accounted for $49 \%$ of complaints and $1 \%$ accounted for a quarter of complaints'.

15 T.H. Gallagher et al., 'Physicians with multiple patient complaints: ending our silence', BMJ Quality and Safety in Health Care 22 (2013) 521-524; see also supra note 14. 
increase and patients become less risk-tolerant and more aware of their rights. ${ }^{16}$ Physicians experience growing pressure to perform according to professional standards/guidelines and to meet best practices in patient-centred care. ${ }^{17}$ Medical progress raises patient expectations of treatment success. Failure is not an option. This ambiance fosters their belief that medical accidents result from individual carelessness, negligence or substandard care rather than from coincidental events or system errors. ${ }^{18}$ This is however, a fallacy. In 1999, the Institute of Medicine (IOM) report To Err is Human ${ }^{19}$ documented that in practice, most medical errors are simply caused by unavoidable human error in a context of system failure. ${ }^{20}$ 'Errors result from faulty systems, not from faulty people.21 Under these circumstances, legal action and punishment backfire by incentivising doctors to conceal errors, which are part of human fallibility. This neither reduces their occurrence nor improves overall safety in patient care. ${ }^{22}$ On the contrary, it promotes practising 'defensive medicine' to avert liability in case of malpractice suits. ${ }^{23}$ As a consequence healthcare costs increase without improving health outcomes. ${ }^{24}$ Health economists agree that, if even average doctors perform medically unwarranted diagnostic tests or treatments to

16 OECD, Medical Malpractice. Prevention, Insurance and Coverage Options, Policy Issues in Insurance no. 11 (Paris: OECD Publishing, 2006) p. 25.

17 H.M. Krumholz, 'Informed consent to promote patient-centered care', JAMA 303 (2010) 1190-1191.

18 D.H. Sohn, 'Negligence, genuine error and litigation', International Journal of General Medicine 6 (2013) 49-56. 'Negligence is failure to meet a standard level of care. It is an incorrect decision. (...) A system error, on the other hand is an occasional, simple human error. Deterrents cannot reduce these errors, because they are made unintentionally'.

19 L.T. Kohn et al., To Err is Human:Building a Safer Health System (Washington, DC: Institute of Medicine, 1999).

20 Ibid. The Iом defines error as 'the failure of a planned action to be completed as intended (i.e. error of execution) or the use of a wrong plan to achieve an aim (i.e. error of planning)'. A system is ' $a$ set of interdependent elements that interact to achieve a common aim'.

21 L. Leape, 'Non-Punitive Approach to Prevention of Medical Errors', Journal of Oral \& Maxillofacial Surgery 63 (8, Supplement) (2005) 16.

22 D.G. Stevenson et al., 'Does litigation increase or decrease health care quality? A national study of negligence claims against nursing homes', Medical Care 51 (2013) 430-436.

23 us Congress, Office of Technology Assessment, Defensive medicine and medical malpractice (Washington, DC: us Government Printing Office, 1994) p. 13.

24 M.M. Mello et al., 'National costs of the medical liability system', Health Affairs 29 (2010) 1569-1577; H. Nys, 'The Factual Situation of Medical Liability in the Member States of the Council of Europe' in: Report to the 2008 Council of Europe Conference 'The Ever-Growing Challenge of Medical Liability: National and European Responses' (Strasbourg: Council of Europe, 2009) pp. 17-41. 
reduce their exposure to malpractice liability, the cure is worse than the disease from society's point-of-view. ${ }^{25}$ Still this is not uncommon in the United States (Us $)^{26}$ and the United Kingdom (UK). ${ }^{27}$ In 2015 the British Medical Association (BMA) expressed concerns, that doctors practiced medicine more defensively and were driven more by fear of litigation than by fear of being reported to the regulator. ${ }^{28}$ This is not different in the rest of Europe. ${ }^{29}$ It raises the question whether and how traditional fault-based civil liability systems or their no-fault alternatives should be adapted to effectively cope with the developments in cost-conscious, patient safety-oriented 21st century healthcare.

\subsection{How to Compensate Medical Injuries?}

When suffering an injury or experiencing an adverse outcome during medical treatment, a patient may sue his doctor for malpractice and seek compensation. His country of residence determines whether his claim is handled within a contractual or tort liability system or a no-fault system. In the first situation, he is financially compensated when it is proven that negligence caused his injury. This implies his treatment was not in line with the required and generally accepted professional standard. ${ }^{30}$ Contractual and tort liability root in the assumption, that the defendant's culpable fault underlies the injury of the claimant ${ }^{31}$ and demands monetary compensation. In a no-fault system evidence of a causal relationship between treatment and injury constitutes the basis for compensation. ${ }^{32}$ There is broad agreement in the medicolegal literature that contractual and tort liability systems do not engage physicians in

25 H. Scherz et al., 'Defensive Medicine: A Cure Worse Than The Disease', Forbes Magazine, 27 August 2013 .

26 A.B. Jena et al., 'Physician spending and subsequent risk of malpractice claims', $B M J 35^{1}$ (2015) h551.

27 O. Ortashi et al., "The practice of defensive medicine among hospital doctors in the United Kingdom', BMC Medical Ethics 14 (2013) 42.

28 A. O'Dowd, 'Doctors increasingly practice "defensive" medicine for fear of litigation, says regulator', BMJ 350 (2015) h87.

29 P. Bertoli, Medical Malpractice in Public Healthcare Systems (Rotterdam: Erasmus University Rotterdam, 2014) pp. 39-45; V. Di Gregorio et al., 'Defensive medicine in Europe: which solutions?', European Journal of Public Health 25 (Supplement 3) (2015) 145.

$30 \quad$ Supra note 18, p. 49.

31 In the Us the person starting a civil action is called plaintiff; in the UK (and the rest of Europe) claimant.

32 However, doctors remain professionably accountable. Supra note 7, p. 6; see also K. Wallis et al., 'New Zealand's 2005 'no-fault' compensation reforms and medical professional accountability for harm', The New Zealand Medical Journal 126 (2013) 33-44. 
improving healthcare. No-fault systems however enhance their participation in institutional efforts to address system errors/failures and increase patient safety. ${ }^{33}$ The following paragraphs discuss key elements of both systems.

\section{Medical Error and Legal Remedies for Damages: Tradition or Innovation?}

In general terms tort law is organised around corrective justice, ${ }^{34}$ distributive justice ${ }^{35}$ and prevention or deterrence. The latter plays a prominent role in how physicians interact with patients. As only doctors are in the position to take (additional) precautionary measures to reduce the probability and/or severity of injury, most medical accidents are unilateral from a legal perspective. ${ }^{36}$ Usually the patient has no influence on suffering injury, and plays a negligible role. ${ }^{37} \mathrm{In}$ a vast majority of medical malpractice cases the claimant is a patient and the defendant a doctor. Hence medical malpractice is probably the area of tort law in which empirical evidence best supports the role of tort liability in providing economic incentives (for measures) to prevent medical injuries. Most relevant data on this subject relate to the us healthcare system..$^{38}$ Considering the major differences in culture and institutional context between the Us and (many countries in) Europe, ${ }^{39}$ extrapolation of American findings to Europe warrants caution and careful scrutiny.

33 D.M. Studdert et al., 'No-Fault Compensation for Medical Injuries. The Prospect for Error Prevention', JAMA 286 (2001) 217-223; M.M. Mello et al., 'Who pays for medical errors? An analysis of adverse event costs, the medical liability system, and incentives for patient safety improvement', Journal of Empirical Legal Studies 4 (2007) 835.

34 Corrective justice is based on the concept that individuals who are responsible for the wrongful losses of others have a duty to repair the losses'; see A. Beever, 'Corrective Justice and Personal Responsibility in Tort Law', Oxford Journal of Legal Studies 28 (2008) 477.

35 Distributive justice relates to (financial) compensation, which the injurer (defendant) provides to the victim (claimant) for any damage the victim suffered as a consequence of the injurer's unduly risky behaviour.

$36 \quad$ B.C.J. van Velthoven et al., 'Medical liability: do doctors care?', Recht der Werkelijkheid 33 (2012) 28-30. In a bilateral accident both parties can be held accountable for their role in causing damage.

37 Ibid. Exceptions may involve situations in which patients do not take their medication as prescribed or refuse to faithfully comply with life style rules in line with their doctor's instruction.

38 Mello et al., supra note 33 .

39 The institutional context involves amongst others medical liability insurance, the structure and financial management of healthcare (institutes), codes of professional conduct for medical practitioners and national regulation of quality \& safety standards. 
The inconsistent definition of medical error in the medicolegal literature complicates correct interpretation of Us/EU data. Generally, it is not clear to what extent negligence is involved: a crucial factor in any medical malpractice lawsuit. From a legal point-of-view it is essential to differentiate injury caused by treatment from injury caused by the disease itself. In a landmark publication on the results of the Harvard Medical Practice Study (HMPS), Brennan et al. introduced the term adverse event for 'an injury that was caused by medical management (rather than the underlying disease) and that prolonged the hospitalisation, produced a disability at the time of discharge, or both'. Negligence was defined as 'care, that fell below the standard expected of physicians in their community'. Adverse events were reported in $3,7 \%$ of all hospitalisations. Negligence was present in only $28 \%$ of those; ${ }^{40}$ see Fig. 1. The majority of patients suffering adverse events is therefore not eligible for compensation through the (tort) litigation system. This was the first publication providing solid empirical evidence of thousands of adverse events in regular healthcare each year. It received international recognition for its scientific quality and is widely cited. ${ }^{41}$ In a follow-up paper the same group of investigators reported that patients claimed compensation in less than $40 \%$ of adverse event cases involving clearly negligent care. ${ }^{42}$ At best just half of these claims was deemed potentially successful in the usual, complicated and acrimonious legal procedure. ${ }^{43}$ As the high incidence of adverse events revealed that complications are an inherent feature of medical interventions rather than the result of unnecessary faults by careless physicians, the impact on the political

40 T.A. Brennan et al., 'Incidence of adverse events and negligence in hospitalized patients: results of the Harvard Medical Practice Study I', New England Journal of Medicine 324 (1991) 370-376. A doctor often precribes an antibiotic in case of a serious bacterial infection. This may cause an unforeseeable allergic reaction with the patient and subsequent kidney failure. If so, the kidney failure constitutes an adverse event. This is by definition not negligence.

41 Google Scholar reports around 5000 hits (26 January 2017). It is considered 'the bestknown study of the epidemiology of medical injury and malpractice claiming'; see D.M. Studdert et al., 'When Tort Resolutions Are "Wrong” Predictors of Discordant Outcomes in Medical Malpractice Litigation', The Journal of Legal Studies 36 (S2) (2007) S47-S78.

42 A.R. Localio et al., 'Relation between malpractice claims and adverse events due to negligence', New England Journal of Medicine 325 (1991) 429; see also A. Kachalia et al., 'New Directions in Medical Liability Reform', New England Journal of Medicine 364 (2011) 15641565 . 'The best estimates are that only $2-3 \%$ of patients injured by negligence file claims, only about half of claimants recover money, and litigation is resolved discordantly with the merit of of the claim (i.e. money is awarded in nonmeritorious cases or no money is awarded in meritorious cases) about a quarter of the time'.

Ibid. 


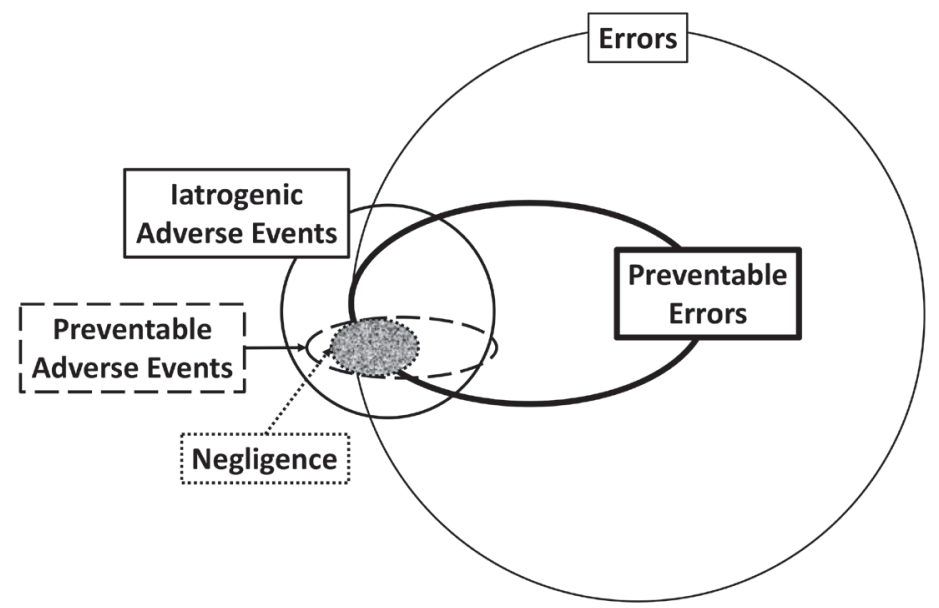

FIGURE 1 Relationship between (preventable) error, negligence and (preventable) events SOURCE: T.P. HOFER ET AL., WHAT IS AN ERROR', EFFECTIVE CLINICAL PRACTICE 6 (2000) 265

and legal landscape was significant. Interest in non-negligence based forms of compensation gained more traction. The effectiveness of tort litigation's quality assurance role in healthcare and specifically the appropriateness of deterrence as a tool to discipline physicians in how they practise medicine was challenged. ${ }^{44}$ The observation from malpractice insurers (US) that less than $1 \%$ of all medical malpractice cases delivered a verdict favouring the claimant ${ }^{45}$ provided further empirical support for this. Another analysis on the outcomes of malpractice litigation (US) confirmed this statistic. ${ }^{46}$ In the Us the tort liability system is therefore consistently criticised for being unfair, slow and (too) costly. ${ }^{47}$ It fails to (justly) compensate patients who suffered injury from proven negligent care, and perversely incentivises defensive medicine. ${ }^{48}$ The

44 Supra note 22, p. 435; see also infra note 84.

45 Supra note 18, p. 51.

46 A.B. Jena et al., 'Outcomes of medical malpractice litigation against us physicians', Archives of Internal Medicine 172 (2012) 892-894. About 45\% of all cases did not progress to litigation. Only $4,5 \%$ of all cases ended in a jury verdict; $80 \%$ favored the physician. Cases the physician won took 39 months; those the claimant won 43,5 months.

47 Mello et al., supra note 24.

48 D.P. Kessler, 'Evaluating the Medical Malpractice System and Options for Reform', Journal of Economic Perspectives 25 (2011) 93-110; see also supra note 18, p. 51. 
medical malpractice crises in the us in the mid-seventies originated in its dysfunctional protection of patients and its excessively high costs. The first problem still exists. ${ }^{49}$ Tort reforms involving caps on compensation of noneconomic damages were however effective in cost reduction. ${ }^{50}$ Mediation led to successful cost containment and more frequent acceptance of the outcome by both parties. ${ }^{51}$ Arbitration was subject of controversy. ${ }^{52}$ Scholars proposed removing medical malpractice claims from the tort system and establishing 'health courts' with medically savvy judges to deter frivolous litigation and prevent miscarriages of justice. ${ }^{53}$ This is in line with the growing consensus in the medicolegal literature that implementation of a no-fault system is in the interest of claimants, doctors and society as a whole. ${ }^{54}$

The us and Europe face similar challenges in coping with medical malpractice. There are, however, fundamental differences in legislation and regulations with respect to compensation of injured patients. ${ }^{55}$ Although also in Europe most malpractice claims are settled in court, some countries take into account

49 D.A. Hyman et al., 'Medical Malpractice and Compensation in Global Perspective: How Does The US Do It?', Chicago-Kent Law Review 87 (2012) 163-198; M.M. Mello et al., 'The Medical Liability Climate and Prospects for Reform', JAMA 312 (2014) 2146-2155.

50 S. Amaral-Garcia, Quantifying the Economics of Medical Malpractice. A View from a Civil Law Perspective, Doctoral Dissertation, Erasmus University Rotterdam, The Netherlands, 2011; chapter 3; see also Kachalia et al., supra note 42, p. 1566.

51 S.J. Szamania et al., 'Alternative dispute resolution in medical malpractice. A survey of emerging trends and practices', Conflict Resolution Quarterly 26 (2008) 71-96.

52 D. Shieh, 'Unintended Side Effects: Arbitration and The Deterrence of Medical Error', New York University Law Review 89 (2014) 1806-1835.

53 A.B. Kachalia et al., 'Beyond negligence: Avoidability and medical injury compensation', Social Science \& Medicine 66 (2008) 387-402; M.M. Mello et al., "Health Courts" and accountability for patient safety', The Milbank Quarterly 84 (2006) 459-492.

54 H.R. Clinton et al., 'Making patient safety the centerpiece of medical liability reform', New England Journal of Medicine 354 (2006) 2205-2208; see also Mello et al., supra note 49 and infra notes 57 and 58 .

55 U. Magnus, 'Why is US Tort Law so Different?', Journal of European Tort Law 1 (2010) 102-124; see also K. Oliphant, 'Medical Malpractice and Compensation: Comparative Observations', in K. Oliphant et al. (eds.), Medical Malpractice and Compensation in Global Perspective (Berlin: De Gruyter, 2013) p. 514. '... liability law in the United States has a number of special features that make it somewhat untypical, and limit its utility as a comparator in cross-jurisdictional investigation, amongst them the role of the jury in deciding upon liability and assessing the damages, the availability of punitive damages, the rule that each party should bear its own legal costs, win or lose, the largest role played by contingency fees, and the availability of extensive pre-trial procedures to require the disclosure of documents and the taking of witness statements'. 
that most medical injuries are not negligently caused and do not qualify for compensation via litigation. With due consideration for patients' rights to adequate redress for iatrogenic injuries they established separate administrative compensation schemes to facilitate (easy access to) out-of-court settlements. ${ }^{56}$ Via this route claims are processed (more) efficiently ${ }^{57}$ and satisfactorily. ${ }^{58}$ When fault and/or causation is/are difficult or impossible to prove, patients' needs and (legal) interests are better served. In Scandinavia no-fault systems basically compensate all medical injuries via collective entities (e.g. patient insurance systems) and prevail over tort litigation. ${ }^{59}$ Since 2002 French law also allows compensation of (serious) harm that is inherent to certain medical procedures, occurred without fault of the practitioner and could not be controlled. ${ }^{60}$ In these legally well-defined circumstances (no-fault) strict liability applies as an exception to fault-based liability, which still underlies the majority of malpractice cases. ${ }^{61}$ The new regulation was the endpoint of a

$5^{6}$ Kachalia et al., supra note 53, p. 388. 'Each of the Nordic countries (...) have abandoned their negligence-based compensation systems (...). The shifts were motivated largely by perceptions that the tort system's adversarialism, combined with the highly specialized knowledge and fact-finding needed in medical injury claims, made the resolution process too long and expensive. A related impetus was concern that the tort system's cumbersome nature impaired patients' access to due compensation'.

57 K. Essinger, 'Medical liability: alternative ways to court procedures', in: Report to the 2008 Council of Europe Conference 'The Ever-Growing Challenge of Medical Liability: National and European Responses' (Strasbourg: Council of Europe, 2009) pp. 42-57 'The percentage of claims solved by courts is less than $1 \%$ in Scandinavian countries, $2 \%$ for ONIAM in France and $4 \%$ for the Litigation Administrative Authority in England. In Germany 40\% of claims are solved in courts, in France 6o\% (most of that is insurance companies) and in Italy 86\%'.

$5^{8}$ Ibid., p. 48. 'Administrative countries or systems are based on special patient right legislation regarding medical injuries. They use administrative procedures out of court for claims handling to a very low cost and probably much shorter median times for decisions. They solve 98\%-99\% of claims out of court'.

59 V. Ulfbeck et al., 'Malpractice in Scandinavia', Chicago-Kent Law Review 87 (2012) 111-129; see also supra note 57 .

6o G. Helleringer, 'Medical Malpractive and Compensation in France. Part II: Compensation Based on National Solidarity', Chicago-Kent Law Review 86 (2011) 1126; L. Ancelot et al., 'Physician-patient relationship and medical accident victim compensation: some insights into the French regulatory system', European Journal of Health Economics 16 (2015) 529-542; and S. Taylor, Medical Accident Liability and Redress in English and French Law (Cambridge: Cambridge University Press, 2015) chapters 2 and 5.

Ibid., Taylor, pp. 27-28; see also supra note 57 . 
fierce national dispute between all stakeholders involved, the Conseil d'Etat, ${ }^{62}$ the Cour de Cassation ${ }^{63}$ and the French government on better compensation for (more) injured patients and stabilisation of liability costs for insurers and healthcare providers. ${ }^{64}$ In 2010 Belgium implemented a comparable two-track system after it adopted more or less similar legislation. ${ }^{65}$ The National Health Service (NHS) Redress Act, which the UK Parliament approved in 2006 to facilitate a more fair out-of-court redress scheme for injured patients, ${ }^{66}$ was however not (fully) implemented. ${ }^{67}$ Instead the uk government(s) took various measures to reduce the frequency and severity of malpractice claims against the state-run NHS. ${ }^{68}$ Still both number and costs of medical negligence claims rise at a significant rate. ${ }^{69}$ Italy is confronted with the same problem(s). ${ }^{70}$

62 The Conseil d'Etat (Council of State) is the highest administrative court in France.

63 The Cour de Cassation (Court of Cassation) is the highest civil court in the French judiciary.

64 S. Taylor, 'The development of medical liability and accident compensation in France', in: E. Hondius (ed.), The Development of Medical Liability (Cambridge: Cambridge University Press, 2010) pp. 70-107.

65 T. Vandersteegen et al., 'Physician Specialists' Perceptions of the Medical Malpractice System in Belgium', European Journal of Health Law 22 (2015) 481-491.

66 Taylor, supra note 6o, p. 14. 'Redress would ordinarily comprise compensation and/or a package of care or treatment, the provision of an explanation, an apology, and providing the patient with a report on the action which had been, or would be taken to prevent similar cases arising in the future. Damages under the scheme would be likely to be limited to $£ 20,000$ '.

67 Taylor, supra note 6o, p. 15. The NHs Redress Act was only partly implemented in Wales.

68 Taylor, ibid., pp. 10-11. These measures involved (1) the introduction of an obligatory protocol to promote out-of-court settlements of claims and avoiding litigation, and (2) the withdrawal of legal aid for the majority of medical negligence claims.

69 Ibid. In England the National Health Service Litigation Authority (NHSLA) indemnifies English NHS Trusts against claims. In 2013/2014 there were 11,945 claims; in 2008/2009 6,088 . In $2013 / 2014$ the NHSLA paid $\pm £ 1,244$ million to settle claims; in $2006 / 2007 \pm £ 580$ million.

70 Bertoli, supra note 29, pp. 45-50. In 2011 the Italian Association of Insurance Companies (ANIA) reported a $252 \%$ increase in the number of malpractice claims against physicians from 9,567 (1994) to 33,682 (2010). The number of claims filed against hospitals rose with $236 \%$. See also D.M. Toraldo et al., 'Medical Malpractice, Defensive Medicine and Role of the "Media" in Italy', Multidisciplinary Respiratory Medicine 10 (2015) 12 '(...) Italy has the highest proportion of health lawsuits settled in court in Europe (more than 9o\%), way ahead of France $(60 \%)$ and Germany $(40 \%)$ and is accordingly in last place concerning health lawsuits settled out of court'. 
In the absence of specific statutory law to regulate the physician-patient relationship, a physician's obligation towards patients is governed by principles of contract law. Injured patients can either sue the physician or the hospital. ${ }^{71}$ In Spain administrative law applies for medical accidents in the public health system. ${ }^{72}$ The Civil Code is the main body of applicable law for harm in private healthcare. ${ }^{73}$ This legal structure may however, not be legal practice:

Although apparently there are different liability rules applicable according to the place of accident, case law shows that these differences have no practical effect. Courts base their decisions on the evidence of negligence; even if the injury took place in a public hospital a strict liability rule will not be applied. ${ }^{74}$

Even so, the number of actions before administrative courts is growing faster than the number of litigations at civil courts. ${ }^{75}$ This is also the trend in France. ${ }^{76}$ Civil Code provisions are the basis for German medical malpractice law; ${ }^{77}$ just

71 Bertoli, supra note 29, pp. 34-38; see also A. Feola et al., 'Medical Liability: The Current State of Italian Legislation', European Journal of Health Law 22 (2015) 347-358.

72 S. Amaral-Garcia et al., 'Do Administrative Courts Favour the Government? Evidence from Medical Malpractice in Spain', Journal of European Tort Law 6 (2015) 246-248; see also M.P. Garcia Rubio et al., 'The Development of Medical Liability in Spain', in: E. Hondius (ed.), The Development of Medical Liability (Cambridge: Cambridge University Press, 2010) pp. 160-187.

73 Ibid.

74 Amaral-Garcia, supra note 72, p. 247.

75 M. Castellano Arroyo et al., 'Medical Responsibility and Liability in Spain', in: S.D. Ferrara et al. (eds.), Malpractice and Medical Liability. European State of the Art and Guidelines (Berlin/Heidelberg: Springer Verlag, 2013) pp. 161-187; P. Giraldo et al., 'A retrospective review of medical errors adjudicated in court between 2002 and 2012 in Spain', International Journal for Quality in Health Care 27 (2015) 1-7; see also supra note 72.

76 Infra notes 126, 129 .

77 M.S. Stauch, 'Medical Malpractice and Compensation in Germany', Chicago-Kent Law Review 86 (2011) 1143: 'Under the Bürgerliches Gesetzbuch [в в в] [Civil Code], the patient generally has the choice of bringing an action in contract or in tort (or in both)'. Hospitals are vicariously liable for actions and/or omissions of employees; see also M.S. Stauch, 'The 2013 German Patients' Rights Act - Codifying Medical Malpractice Compensation', Journal of European Tort Law 6 (2015) 85-94. In 2013 the German Parliament enacted the Patients' Rights Act (Patientenrechtegesetz) into law, which codified German case law on medical injury liability rules within the в вв as a new codal subsection entitled 'Treatment Contract' (Behandlungsvertrag). This reaffirmed contract law as the primary legal basis for malpractice litigation. '(...) from the perspective of the patient, there is now 
like in Poland ${ }^{78}$ and the Netherlands. ${ }^{79}$ The number of malpractice claims in Germany is among the highest in Europe. During the past decade, however, only $8 \%$ resulted in litigation involving breach of contract. 'The rest are settled by the doctor/hospital's liability insurer or abandoned, in some cases following adjudication by an arbitration board' ${ }^{80}$ Overall most European countries address medical malpractice primarily via fault-based contract and/or tort law. ${ }^{81}$ Also in Europe the legal focus is primarily on doctors' duties and less on patients' rights. Compensation of injured patients depends on proving the doctor's negligence and its causal relationship with their personal injury: a (medically) complex and daunting task.

\section{Compensation via No-fault Systems: A Mixed Bag}

Compared to contract and tort litigation, no-fault systems appear to result in more quick, more fair and more reliable compensation of injured patients. ${ }^{82}$ They operate independently of courts. Proof of negligence is not required. Facilitation of blame-free reporting and evaluation of medical errors by healthcare providers is considered their most compelling advantage. This is essential to improve organisational learning, healthcare quality and

a specific part of the Civil Code to which they can refer for their key entitlements in relation to (injurious) medical treatment' (p. 94).

78 K. Baczyk-Rozwadowska, 'Medical Malpractice and Compensation in Poland', ChicagoKent Law Review 86 (2011) 1217-1261. Injured parties in Poland prefer the tort liability regime.

79 E. Hondius, 'Medical Liability in The Netherlands', in: E. Hondius (ed.), The Development of Medical Liability (Cambridge: Cambridge University Press, 2010) p. 137 “The Dutch legislature has opted for the private law solution and within this for contract and not tort as a basis'.

8o Stauch 2011, supra note 77, p. 1162; see also Law Library of Congress, Medical Malpractice Liability: Germany, June 2009; last updated 6 June 2015. 'Medical malpractice claims are mostly settled with the liability insurers, often after mediation services of the medical associations or the social health insurers have given expert opinions. (...) German awards for tangible damages are low because most of the losses resulting from personal injury are borne by the social security system'.

81 Supra note 57, p. 43; see also C.M. Romeo-Casabona, 'The legal approach to medical liability. Negligence and breach of patient's autonomy', in: Report to the 2008 Council of Europe Conference 'The Ever-Growing Challenge of Medical Liability: National and European Responses' (Strasbourg: Council of Europe, 2009) pp. 109-119.

82 J. Dute, 'Medical Malpractice Liability: No Easy Solutions', European Journal of Health Law 1 (2003) 85-90; Kachalia et al., supra note 53. 
patient safety. ${ }^{83}$ Critics dispute these observations and are concerned about their (potential) undermining of tort law's deterrence and damage-preventive effect. ${ }^{84}$ Erosion of physician accountability may expose patients to more rather than less risk of harm. Health-economists argue that no-fault systems may be associated with significantly more claims and hence even higher healthcare costs; unless compensation is capped at a lower level than current tort awards. ${ }^{85}$ They doubt whether this serves the interests of injured patients. ${ }^{86}$ Finally legal scholars question the compatibility of a fully-fledged no-fault system with (positive obligations of) the European Convention of Human Rights (ECHR), if this would deny injured patients access to courts. ${ }^{87}$ This seems an academic concern rather than a legal reality. In European countries with operational no-fault systems injured patients can also be compensated under the rules of contract and/or tort law. ${ }^{88}$

In 1975 Sweden was the first Scandinavian country to adopt a 'no-fault' system. ${ }^{89}$ Initially it involved a patient insurance scheme with a voluntary and private character. ${ }^{90}$ In 1997 the Patient Injury Act (PIA) placed it on a statutory footing. ${ }^{91}$ Care providers are legally obliged to have patient insurance to cover liability for injury compensation. ${ }^{92}$ Patients can file claims without incurring

83 Studdert et al., supra note 33. For specific (dis)advantages of 'no-fault' systems see A.M. Farrell, No-Fault Compensation Schemes for Medical Injury: A Review (Scottish Government Social Research, 2010).

84 B.R. Furrow, 'The Patient Injury Epidemic: Medical Malpractice Litigation As A Curative Tool', Drexel Law Review 4 (2011) 41-107.

85 T. Vandersteegen et al., 'The impact of no-fault compensation on health care expenditures: An empirical study of OECD countries', Health Policy 119 (2015) 367-374.

86 Supra note 48, p. 104.

87 S.A.M. McClean, No-Fault Compensation Review Group. Report and Recommendations. Volume I (Edinburgh: The Scottish Government, 2011) chapters 4 and 5. This concerned Articles 2, 6, 8, 13 ECHR.

88 Ulfbeck et al., supra note 59, p. 116. Denmark is the exception among the Scandinavian countries. For information on France see Helleringer, supra note 6o. For information on Belgium see supra, note 65 .

89 Finland followed in 1987, Denmark in 1988 and Norway in 1992.

9o Farrell, supra note 83, p. 32. Swedish hospitals established an insurance company for medical injuries to avoid court procedures and to compensate patients more satisfactorily.

91 Ulfbeck et al., supra note 59, p. 114. Originally Patientskadelag (Svensk författningssamling [SFS ] 1996:799), which in English is mostly referenced as Patient Injury Act. Finland adopted a similar Act in 1986. Norway followed in 2001 and Denmark in 2010.

92 Under the Health and Medical Services Act (1982) 17 county councils and 4 regional bodies are responsible for most medical services. Their common insurer, Landstingens Ömsesidiga Försäkringsbolag (LÖF; The County Council's Mutual Insurance Company) 
legal expenses. They are compensated, if upon subsequent evaluation their injury 'could have been avoided'; 93 for instance with an equally effective, yet intrinsically different medical procedure or treatment. ${ }^{94}$ In line with the Tort Liability Act (1972) a patient can also opt to go to court. ${ }^{95}$ The insurer's patient insurance then works as a liability insurance ${ }^{96}$ In practice $99,9 \%$ of all claims is solved out of court. ${ }^{97}$ Health care professionals appreciate the PIA because it allows 'blame-free' reporting and analysis of medical errors, and does not involve punitive sanctions (in court) nor any disciplinary action by the Swedish Medical Responsibility Board (Hälso-och Sjukvårdens AnsvarsNämnd; HSAN). ${ }^{98}$ In case of an unforeseen medical accident, they feel comfortable to encourage and even support injured patients to get compensation. ${ }^{99}$ Publications on the overall performance and social acceptance of the Scandinavian no-fault

handles all patient malpractice claims. Since private care providers have contracts with the county councils, they fall under the same insurance scheme. A patient can apply to the Patientsförsäkringsföreningen (Patient Insurance Association), if a care provider lacks patient insurance; see H. Johansson, 'The Swedish system for compensation of patient injuries', Upsala Journal of Medical Sciences 2010; 115: 88; A. Anell et al., 'Sweden: Health System Review', Health Systems in Transition 14 (2012) 1-159; and supra note 59, pp. 114-115.

93 Farrell, supra note 83, p. 40.

94 This is known as 'the alternative rule'. LöF's daughter company Personskaderegelering [(PSR); Swedish Medical Injury Insurance (SMII)] processes more than $90 \%$ of all claims. About $45 \%$ of them qualify for compensation. If PSR's decision and/or the proposed compensation isn't acceptable for the patient, he/she can appeal to the Patients Claims Panel (PCP). Although PCP's opinion is advisory, the insurer in principle always acts accordingly. In only $10 \%$ of the appeals PCP reaches a different conclusion than PSR. A patient can make a final appeal at the (Swedish) Court of Appeal. This is an arbritation process. The Court's decision is final and binding; see supra note 92 (Johansson, p. 89); see also World Bank, Medical Malpractice Systems Around the Globe: Examples from the US Tort Liability system and the Sweden-No-fault System (Washington, DC: World Bank, 2003) p. 11. Supra note 59, p. 116. This applies to all Scandinavian systems except for the Danish system.

96 Ibid. 'The few malpractice cases that do go to court, therefore most often concern injuries that the patient insurance does not cover'.

97 Farrell, supra note 83, p. 35; see also Di Gregorio, supra note 29: 'In countries where a nofault system (...) is in force, most of the litigations are disputed out of the court of law: the claims resolved in court are $0.1 \%$ in Sweden, $0.3 \%$ in Finland, $0.5 \%$ in Denmark (...)'.

98 Still there are mechanisms to deter medical malpractice. Supra notes 32,59 (Ulfbeck et al., p. 113), 82 (Dute, pp. 88-89) and 92 (Anell, pp. 45-47).

World Bank, supra note 94. 
systems indicate, that they enjoy a fair degree of support and are efficient in terms of cost and time. ${ }^{100}$

Until 2002, French patients had to sue their healthcare provider(s) to obtain compensation for treatment-related injuries. Proof of fault was indispensable for success. ${ }^{101}$ Administrative courts handled claims for injuries in state-run public hospitals. Civil courts judged cases involving private practitioners or institutions. ${ }^{102}$ Disparities in their handling of similar claims were common, led to manifest injustice and in the end also contributed to a 'national crisis' involving patients, physicians, institutions, insurers and even the Conseil d'Etat and the Cour de Cassation. ${ }^{103}$ In 2002 the French Parliament enacted major reforms via legislation (i.e. the Kouchner Act), ${ }^{104}$ clarified and harmonised existing medical malpractice liability rules, ${ }^{105}$ and created a complementary

100 Supra note 87, p. 32; see also M. Erichsen, 'The Danish Patient Insurance System', Medicine \& Law 20 (2001) 355-369.

101 For review of medical liability in France before 2002 see Taylor, supra note 64, pp. 77-92.

102 Taylor, supra note 6o, pp. 28-30. The French secondary healthcare sector consists of public, private non-profit and private profit-oriented hospitals. In 2011 there were 938 public hospitals with 255,758 beds and 1,747 private clinics, providing 156,239 beds. Primary care is private. The relationship between patient and primary care doctor or private clinic is contractual.

103 Taylor, supra note 6o, chapters 2, 5. The Cour de Cassation and the Conseil d'Etat did not (fully) respect each other's case law. Liability costs for insurers skyrocketed after the Perruche case. Insurance premiums for 'high-risk physicians' (e.g. obstetricians and surgeons) exploded. Patients lamented about excessively high litigation costs and the long lag time between filing a claim and obtaining a court decision. Politicians felt, that the rules for medical liability had become unfair and too complex. France was copying the American litigation culture; see also D. Thouvenin, 'French Medical Malpractice Compensation since the Act of March 4, 2002: Liability Rules Combined with Indemnification Rules and Correlated with Several Kinds of Proceedings', Drexel Law Review 4 (2011) 166-167; J. Barbot et al., "No-fault" compensation for victims of medical injuries. Ten years of implementing the French model', Health Policy 114 (2014) 237-245.

104 The legislation involved 1) Loi no. 2002-203 du 4 mars 2002 'relative aux droits des malades et à la qualité du système de santé' (Loi Kouchner) [Law nr. 2002-203 of March 42002 on Patients' Rights and Quality of the Health System Act' (Kouchner Act)] and 2) Loi no. 2002-1577 du 30 décembre 2002 'relative à la responsabilité civile médicale'(Loi About) [Law nr. 2002-1577 of December 30, 2002 on Medical Civil Liability (Law About)]. The latter law became known as the Revised Kouchner Act.

105 F. G'Sell-Macrez, 'Medical Malpractice and Compensation in France. Part I: The French Rules of Medical Liability since the Patients' Rights Law of March 4, 2002', Chicago-Kent Law Review 86 (2011) 1095. 
legal route to get compensation 'quickly' and more easily. ${ }^{106}$ Its provisions were incorporated in the French Code de la santé publique (csP; Public Health Code). This established the current French no-fault scheme. It has the same liability basis for healthcare professionals in the public and private sector. ${ }^{107}$ The traditional fault-based liability rules were not abandoned. ${ }^{108}$ Art. L 1142-1 CSP unambiguously reaffirms the principle that healthcare professionals ${ }^{109}$ and organisations can only be liable on the basis of fault. ${ }^{110}$ In line with Art. L 1142-2 CSP they should now all carry civil liability insurance. ${ }^{111}$ Whether an injured patient initiates a procedure within the new no-fault scheme or files a lawsuit for negligence under the traditional administrative, civil and criminal liability regimes, the initial stage remains fault-oriented in both situations. He can even pursue similar claims in parallel. ${ }^{112}$ 'Litigation and out-of-court settlements are

106 This route fits the French socio-legal tradition to facilitate the compensation of accident victims as a mechanism of social solidarity and loss distribution. Nevertheless it only compensates harm, that was the consequence of 'the occurence of an accidental risk inherent to the medical procedure and which occurred without any fault of the practitioner and could not be controlled'. This includes claims for so-called 'aléa thérapeutique'; see supra notes 60 (Helleringer), 60 (Taylor, p. 25; pp. 61-63) and 103 (Thouvenin; pp. 176-186).

107 Supra note 105, p. 1097. 'The Patients' Right Law of March 4, 2002, modifies the legal basis for medical liability, which is now regarded as a "legal regime" that is neither contractual nor tortious. This change has been very recently confirmed in an important decision of the Cour de Cassation on January 28, 2010, which merely mentions Article L 1142-1 of the CSP without referring to Article 1147 of the Civil Code like previous decisions usually did'; see also Taylor, supra note 6o, p. 30. 'Recent case law has confirmed that (...) medical accident liability law is now considered by the courts as a statutory liability ('responsabilité légale') independent of contract'.

108 According to Art. 1382 of the (French) Civil Code one is liable for the harm caused to another by one's fault.

109 The list of health professionals includes amongst others doctors, dentists, midwives, pharmacists and nurses.

110 Supra note 64, pp. 27, 29-30, 37-42. This article, however, also provides for exceptions to fault liability for harm (e.g. accidents, caused by a defective medical product or a hospital-acquired infection) to shield health professionals and liability insurers from excessive liability that was established in previous case law from the Conseil d'Etat and the Cour de Cassation; see also supra note 105, pp. 1098-1099.

111 Until 2002 this was not compulsory. The new rule 'forced' insurers to also cover 'high-risk physicians'. Articles L 1142-25 and 26 CSP provide for criminal sanctions in the absence of insurance; see P. Pierre, 'The Role of Insurance in Compensation for Medical Injuries since the Kouchner Act', Drexel Law Review 4 (2011) 155; see also supra note 105, p. 1118.

112 This is in accordance with Art. 6 ECHR. Access to the courts is a fundamental right with no exceptions. See supra notes 60 (Taylor, p. 24) and 87. 
two separate ways of seeking compensation, even though victims will not be compensated twice for the same medical injury'.13

To start a procedure under the no-fault scheme a seriously injured patient ${ }^{114}$ must submit his case to a Commission Régionale de Conciliation et d'Indemnisation [CRCI; Regional Conciliation and Compensation Commission] ${ }^{115}$ to assess not only whether his harm was an abnormal consequence of the medical act or omission given his prior health status and its foreseeable evolution ${ }^{116}$ but also whether his harm reached the legally required level of seriousness. ${ }^{117}$ The CRCI is strict in rejecting cases not fulfilling both criteria. ${ }^{118}$ Lack of (national) uniformity and consistency in the interpretation of the legal definition of 'medical accident' however was and still is a structural weakness in the procedure. ${ }^{119}$ Only cases, that meet the legal threshold, undergo full medical expert review to validate the patient's harm, its causes as well as its nature and extent. ${ }^{120}$ The report is subject of a public, full case CRCI-examination,

113 Barbot et al., supra note 103, pp. 238-241.

114 If the medical accident caused the patient's death, this can be done by a relative or legal representative. Patients with 'minor' injuries cannot start this procedure. They have to sue for damages in court.

115 In line with Art. L 1142-6 CSP a CRCI is chaired by a judge and comprises representatives of patients, health professionals and insurers. Décret no. 2014-19 of 9 January 2014 capped the number of members to 12; see Thouvenin supra note 103, pp. 176-185 for review of their responsibilities and functioning.

116 Harm, which may be in line with the natural progression of a patient's illness, does not constitute a medical accident; see Taylor, supra note 6o, pp. 99-100.

117 Art. D 1142-1 CSP; see Taylor, supra note 64, p. 94. 'An accident will be considered as sufficiently serious where the victim experiences a predefined minimum level of injury as a result of the accident. (...) The minimum level of invalidity required to benefit from the scheme is set at $24 \%$. A medical accident will also fulfill the criteria of seriousness where the patient suffers a temporary inability to work for six months, or, exceptionally, where the victim is declared permanently inapt to exert his chosen profession, or where the accident causes him 'particularly serious problems', which can include financial problems'.

118 Taylor, supra note 6o, pp. 58, 104, 110-112. For $201337 \%$ of cases was rejected. In $62 \%$ of those the harm was judged to be not sufficiently serious. The decision's validity is questionable. Most claims are poorly documented. CRCI decisions are often 'only' based on a simple medical certificate by the family doctor, without a (second) opinion of a specific medical expert and without a hearing.

119 Taylor, supra note 6o, pp. 101-104.

120 Ex Arts. L 1142-11 and 12 CSP CRCI's select experts from a national list of competent medical experts, as established by the Commission Nationale des Accidents Médicaux [CNAMed; National Commission on Medical Accidents]. For characteristics and role of experts see Thouvenin, supra note 103, pp. 180-183; and CNAMed, Rapport au Parlement et au Gouvernement. Année 2013, pp. 8-12. 
which precedes its decision on the applicable compensation regime. ${ }^{121}$ In case of fault the insurer (of the healthcare provider) is to pay the compensation; ${ }^{122}$ in case of no-fault the Office National d'Indemnisation des Accidents Médicaux (oNIAM; National Office for the Compensation of Medical Accidents). ${ }^{123}$ ONIAM also compensates the claimant if the insurer refuses to pay or the insurance policy does not cover the damage. ${ }^{124}$ Since CRCI decisions are not legally binding, ${ }^{125}$ the insurer, ONIAM and even the patient may still opt to take the case to court afterwards: 'secondary litigation.' ${ }^{26}$ The increasing number

121 CRCI's don't determine the level of compensation! Ex Art. L 1142-6 CSP the claimant can comment on expert observations and conclusions. CRCI's decide by consensus or by vote. Ex Art. L 1142-8 CSP a CRCI must reach a final decision within 6 months after the start of the procedure. In 2013 this took on average 7,8 months, while compensation was awarded in $44 \%$ of accepted cases. If the claimant disagrees with the CRCI's damage assessment, he can end the procedure and sue for damages in court. However if his lawsuit is not successful, he will receive no compensation at all; see supra notes 60 (Taylor, pp. 56-58), 103 (Barbot et al., pp. 238-243) and 103 (Thouvenin, p. 185).

122 Ibid. Ex Art. L 1142-14 CSP the insurer must offer the claimant a settlement payment within 4 months after the CRCI decision. Upon his acceptance the insurer should pay him within a month. This is a transaction in line with art. 2044 of the (French) Civil Code, and hence ends any subsequent litigation based on the same claim. If the claimant deems the insurer's offer unsatisfactory, he can take the insurer to court; see also Ancelot, supra note 6o, p. 532 .

123 Ex Art. L. 1142-17 CSP. Publications in English also refer to on IAM as the 'Public Guarantee Fund', as it is state-funded through taxation and social security. In 2013 and 2014 ONIAM complied with the CCRI's decision in 91,7 and $91,1 \%$ of cases respectively. If a claimant considers ONIAM's settlement proposal not sufficient, he can sue ONIAM ex Art. L 1142-20 CSP. This is rare. In $201497 \%$ of claimants accepted onIAM's offer. For review of ONIAM's legal background, funding and functioning see oniAm, Rapport d'Activité 2014 and supra notes 60 (Helleringer) and 111 (Pierre, pp. 151-164).

124 In this situation ONIAM acts as financial guarantor and sort of (public) 'not-for-profit insurer of last resort'. Ex Art. L 1142-14 CSP ONIAM can take the insurer to court to have these expenses reimbursed.

125 Thouvenin, supra note 103, p. 184. The Conseil d'Etat (in 2007) and the Cour de Cassation (in 2010) ruled that CRCI's 'are administrative commissions whose mission is to facilitate, by preparatory measures, a possible amicable settlement of disputes related to medical accidents. Because a Commission pronounces an opinion, both Courts agree that the opinion issues by a Commission does not bind the insurer'.

126 Art. L 1142-20 CSP. In case of fault the patient can also sue for damages in the criminal courts. Under French criminal law a doctor is criminally liable for a patient's harm upon proof of fault, causation and harm. 
of actions contesting CRCI- and/or ONIAM-decisions in court ${ }^{127}$ suggests that the quality and consistency of decision-making on key elements of the nofault scheme are subject of growing (legal) controversy. ${ }^{128}$ It illustrates how the legal complexity of (implementing) an administrative compensation scheme to better facilitate claims of (the most seriously and vulnerable) injured patients with due consideration for its financial sustainability compromises its transparency, fairness and acceptance. The French experience is an example of how operating a no-fault scheme in the context of traditional civil liability law may gradually lead to an even more tangled web of (sometimes contrasting) rules with different liability principles for separate patient categories; ${ }^{129}$ see Fig. 2. From this perspective it is surprising that, despite the remarkable growth in the complexity and number of medical acts - and hence an inherent surge in medical accidents —, litigation rates did not increase accordingly in the past decade. ${ }^{130}$ It is tempting to attribute this to the inversely proportional growth in the number of cases submitted to and processed by CRCI's. ${ }^{131}$ Although this relationship has so far not been formally validated, the observation itself confirms that an out-of-court settlement scheme can operate effectively as a credible and patient-friendly alternative next to redress through the courts. ${ }^{132}$ Overall its performance did also not negatively affect the overall positive opinion of French patients about their health system. ${ }^{133}$

In 2010 Belgium introduced a similar dual track liability system for medical malpractice. ${ }^{134}$ Its legal basis, structure and operation resemble the French

127 ONIAM, supra note 123, pp. 28-29. Claimants have to sue ONIAM for CRCI judgements. Art. L 1141-20 CSP does not allow court actions against the CRCI, because its judgements are defined as merely preparatory for ONIAM's decision. The number of court actions versus ONIAM at completion of the no-fault procedure grew from 751 in 2011 to 1421 in 2014.

128 This relates to legal unclarity about the access criteria for the no-fault scheme; see supra notes 60 (Taylor, chapter 5 ) and 103 (Barbot et al., p. 244).

129 The existence of separate administrative and civil courts and their legally unrestricted application of different rules to different patient categories is in itself a source of legal uncertainty.

130 Taylor, supra note 6o, pp. 81-82, 85-87.

131 ONIAM, supra note 123, pp. 20-21. This number rose from 1719 in 2003 to 4479 in 2014. Between 2010 and 2014 compensation was awarded in 32-36\% of these cases.

132 S. Taylor, 'Providing Redress for Medical Accidents in France: Conflicting Aims, Effective Solutions?', Journal of European Tort Law 2 (2011) 57-76.

133 K. Chevreuil et al., 'France: Health System Review', Health Systems in Transition 12 (2010) 42. '(...) $80 \%$ of patients were satisfied with the current organization and funding basis of the health care system (...)'; see also L Degos et al., 'Can France keep its patients happy?', BMJ 336 (2008) 254-257.

134 Supra note 65; infra note 136 . 


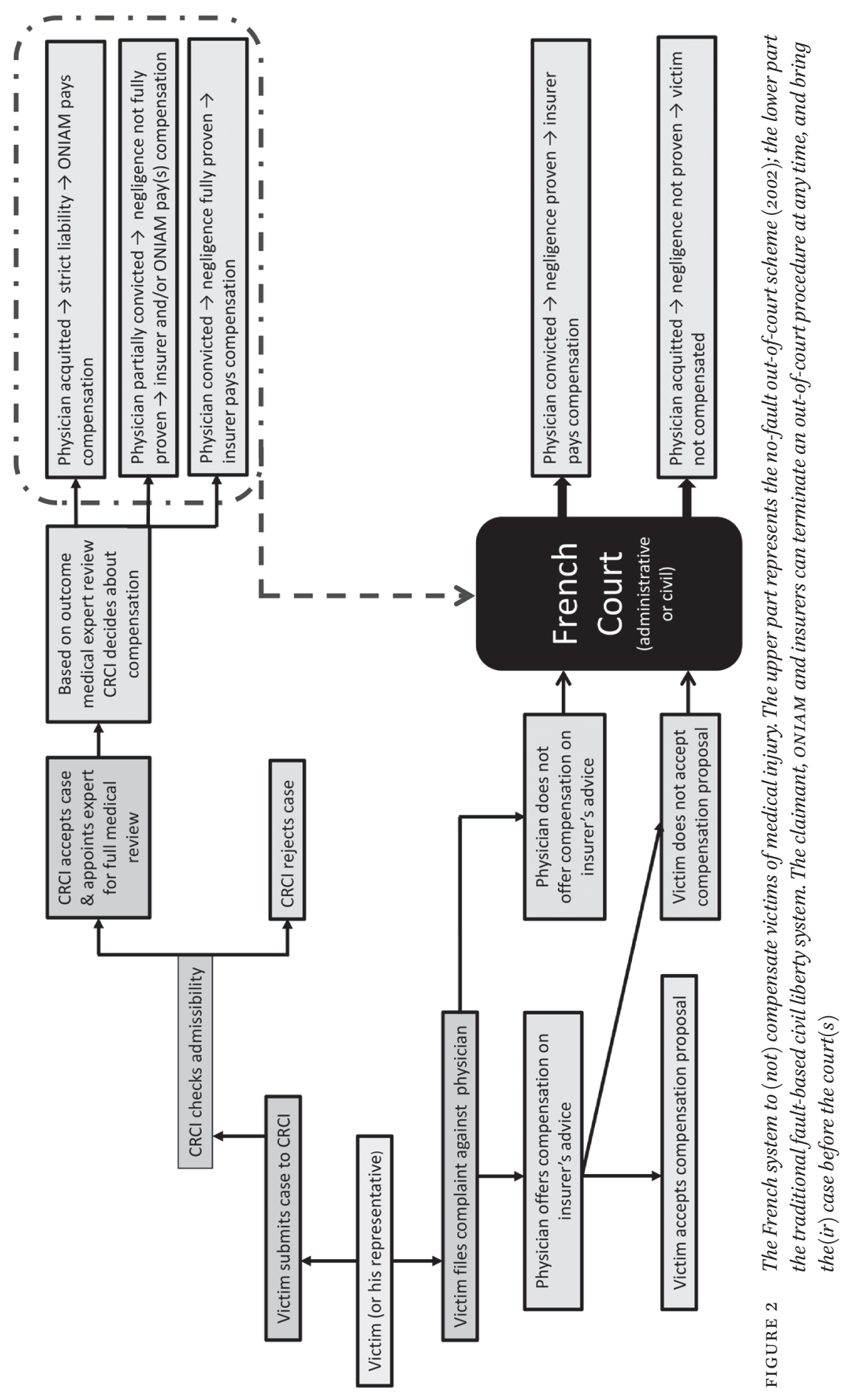


system. Its no-fault scheme involves a Fund for Medical Accidents (FMA), which indemnifies patients in case of non-negligent injuries with abnormal and serious harm. ${ }^{135}$ In the absence of adequate, published data and statistics on its performance little is known about its effectiveness in achieving the government's objective with respect to improving patient (access to) compensation. ${ }^{136}$

4

\section{Conclusion}

Following the Iом's reporting, that most medical errors result from faulty systems rather than from individual carelessness or professional negligence, structural improvement of patient safety became one of the Eu's healthcare priorities. ${ }^{137}$ The EU recognised 'that just and blame-free reporting and learning systems have proven to be excellent tools to increase patient safety culture.'138 This is at odds with traditional fault-based civil liability law. ${ }^{139}$ It may increase patients' trust in physicians, yet this does not affect their propensity to sue. ${ }^{140}$ More disclosure of medical injury to patients is associated with more litigation. ${ }^{141}$ As long as healthcare providers are not exempt from civil liability when reporting legally sensitive fault-related information, their cooperation to improve organisational learning and hence patient safety will remain

135 Ibid.; see also Taylor, supra note 6o, p. 103. The Belgian criteria for 'seriousness' apply to entitlement for no-fault compensation and not for access to the no-fault scheme itself as in France.

${ }_{13} 6$ T. Vandersteegen, Essays on the Medical Malpractice Reform in Belgium. A Law and Economics Analysis (Hasselt: University of Hasselt, 2016).

137 Council of the European Union, Council Recommendation of 9 June 2009 on patient safety, including the prevention and control of healthcare-associated infections, Official Journal of the European Union 52 (2009) 1-6, Notice No 2009/C 151/01; see also European Commission, Patient Safety and Healthcare Associated Infections. Report of the Commission to the Council [сом (2014) 371].

138 Council of the European Union, Council conclusions on patient safety and quality of care, including the prevention and control of healthcare associated infections and antimicrobial care, Official Journal of the European Union 57 (2014) 8 Notice No 2014/C 438/05.

139 O. Quick, 'Patient safety and the problem and potential of law', Journal of Professional Negligence 28 (2012) 82 .

140 A.W. Wu et al., 'Disclosing medical errors to patients: It's not what you say, it's what they hear', Journal of General Internal Medicine 24 (2009) 1012-1017.

141 D.M. Studdert et al., 'Disclosure of Medical Injury to Patients: An Improbable Risk Management Strategy', Health Affairs 26 (2007) 215-226. 
troublesome. ${ }^{142}$ No-fault systems perform better in this respect with Sweden as classic example. ${ }^{143}$ In Sweden victims of medical accidents have full access to traditional litigation, yet practically all cases are settled out of court; often with (full) support of their physician(s). ${ }^{144}$ This may relate to the fact that all patients are entitled to no-fault compensation. ${ }^{145}$ France and Belgium restrict this to the most serious cases. Even then these patients still face legal hurdles and uncertainties to establish their eligibility. The French system however also provides evidence of (growing) social acceptance and (legal/financial) viability of (introducing) a no-fault compensation scheme in a country with a historical tradition of malpractice litigation in courts. Pan-European harmonisation of medical liability rules may seem illusory, ${ }^{146}$ yet the relative 'success' of the transitional French system suggests it is not impossible.

142 Taylor, supra note 6o, pp. 152-156.

143 Supra note $87, \mathrm{p} .3^{2}$. The promotion of safety and quality of care by learning from medical error and moving away from attributing blame are among the legal and social goals of the Swedish system.

144 Ibid. Health practitioners facilitate $60-80 \%$ of all claims.

145 This also applies to other Scandinavian countries and New-Zealand.

146 V. Paskalia, 'Cross-border Healthcare in the EU: And What if Something Goes Wrong?', European Journal of Health Law 23 (2016) 1-16. 